American Journal of Environmental Sciences 7 (6): 534-541, 2011

ISSN 1553-345X

(C) 2011 Science Publications

\title{
The Negative Environmental Changes on the Sea and its Impact on the Aspects of Economic, Social and Health of the Fishermen Living in the East Coast Zone of Peninsular Malaysia
}

\author{
Bahaman Abu Samah, Hayrol Azril Mohamed Shaffril, \\ Jeffrey Lawrence D'Silva and Jegak Uli \\ Laboratory of Sustainable Development and Agriculture Extension, \\ Institute for Social Science Studies, University Putra Malaysia, Malaysia
}

\begin{abstract}
Problem statement: The sea has never been the same as before. Due to the environment and human factors, lot of negative environmental changes can be detected at the sea. Apparently, one of the main dependents of the sea which is the fishermen has the potential to be affected with such changes. Approach: This study would like to discover whether these changes have affected the aspects of economic, social and health of the fishermen living in the east coast zone of Peninsular Malaysia. This is a quantitative study where a total of 300 fishermen have been selected as the respondents. The number was gained from four states in the east coast zone of Peninsular Malaysia namely Kelantan, Terengganu, Pahang and East Johor. Results: The instrument used for this study is a developed questionnaire that was pre tested earlier before the actual data collection conducted. To gain the data needed, survey was employed. Based on the results gained it can be seen that the negative environmental changes that occurs on the sea have moderately affected the aspects of economic, social and health of the fishermen living in the east coast zone of Peninsular Malaysia. Conclusion/Recommendations: It is recommended that the fishermen all over Malaysia should be provided with information on the potential impacts of the negative environmental changes on the sea so that they can prepare themselves to face these negative changes.
\end{abstract}

Key words: East coast zone, fishermen, negative environmental changes, economic, social and health

\section{INTRODUCTION}

Development can be achieved in many ways; in Malaysia for example, it can be achieved through agriculture and ICT (Uli et al., 2010; D'Silva et al., 2011; Samah et al., 2011). Nevertheless, fisheries industry has established itself as one of the important industries for Malaysia development. The role played by this industry in ensuring the consistency of the food supply cannot be denied. Based on the recent statistic found at the official website of Department of Fisheries Malaysia

(DOF),(http://www.dof.gov.my/c/document_library/get _file?uuid=cee94589-7180-4797-a1e2-93907fd42578 and groupId=172176)F) informed that in 2009, almost 1,392 million tonnes metrics of marine fishes have been landed by the Malaysian fishermen. Unquestionably, this sector has become one of the main contributors to achieve the mission of making agriculture as the third income generator for Malaysia.
Besides of the significance of this industry, to sustain the marine productivity will become a major concern. As been admitted by the Malaysian fishermen, the environment has changed a lot and it indeed affects the sea (Shaffril et al., 2011). If this happens, besides of bringing a lot of negative impacts to the sea, it will bring threats to the aspects of economic, social and health of the fishermen. A lot of previous international studies have proven that the environmental changes have affected these three aspects, but does the same thing happens in Malaysia? This is the main query that needs to be solved in this study; do the environmental changes caused by environmental and human factors have any effects on the aspects of economic, social and health of the fishermen living in the east coast zone of Peninsular Malaysia?

Fishermen at the east coast zone of peninsular Malaysia: Before going to the main objective of the

Corresponding Author: Bahaman Abu Samah, Laboratory of Sustainable Development and Agriculture Extension, Institute for Social Science Studies, University Putra Malaysia, Malaysia 
study, it is better to have some basic information on the fishermen living in the east coast zone of Peninsular Malaysia. Table 1 has clarified the information related to the recent number of registered fishermen and vessels in the east coast zone of Peninsular Malaysia. In total there are 17 fisheries district in this zone in which 4 fisheries districts can be found at East Johor, 3 fisheries districts can be found at Pahang, 7 fisheries districts can be found at Terengganu and 3 fisheries districts can be found at Kelantan. Terengganu has come out with the highest number of registered fishermen at this zone with 10421 registered fishermen while East Johor Bharu is the district that comes out with the lowest number of registered fishermen with 553 registered fishermen. Overall there are 33,118 registered fishermen in the east coast zone of Peninsular Malaysia thus depicting that there are a big number of community that depends on the sea for their income and protein sources and it can be conceived on how much they are affected due to the changes that occur on the sea. In term of registered vessels, overall, there are a total of 8894 registered vessels at the east coast zone of Malaysia in which Kuantan is the district that come out with the highest number of registered vessels (873) followed by Pekan (702) and Tumpat (700). Setiu is the district that has the lowest number of registered vessels (232).

Table 1: Recent statistic of registered fishermen and vessels in east coast zone of Malaysia

\begin{tabular}{llcc}
\hline State & District & $\begin{array}{c}\text { Number of } \\
\text { registered } \\
\text { fishermen }\end{array}$ & $\begin{array}{l}\text { Number of } \\
\text { registered } \\
\text { vessels }\end{array}$ \\
\hline East Johor & East Johor Bahru & 553 & 551 \\
& North Kota Tinggi & 1134 & 317 \\
& (Td. Sedili) & 1321 & 621 \\
& South Kota & \\
& Tinggi (Pengerang) & & 586 \\
Total & Mersing & 3041 & $\mathbf{2 0 7 5}$ \\
Pahang & Kuantan & $\mathbf{6 0 4 9}$ & 873 \\
& Pekan & 3720 & 703 \\
Total & Kuala Rompin & 1317 & 417 \\
Terengganu & Kemaman & $\mathbf{7 0 2 4}$ & $\mathbf{1 9 9 3}$ \\
& Dungun & 1874 & 564 \\
& Marang & 1196 & 489 \\
& North Kuala & 1224 & 430 \\
& Terengganu & 876 & 309 \\
& South Kuala & 2135 & 481 \\
& Terengganu & & \\
Total & Besut & 2356 & 401 \\
Kelantan & Setiu & 760 & 232 \\
& Kota Bharu & $\mathbf{1 0 4 2 1}$ & $\mathbf{2 9 0 6}$ \\
& Bachok/ & 1450 & 518 \\
Total & Pasir Puteh & 6430 & 700 \\
Overall total & Tumpat & 1744 & 702 \\
\hline & & $\mathbf{9 6 2 4}$ & $\mathbf{1 9 2 0}$ \\
& & 33118 & 8894 \\
\hline & & &
\end{tabular}

Has the sea changed? What are the possible factors that contribute to it?

Climate change-global warming: The global warming; everybody know about this as it has become a global phenomenon and it became worsen day by day and year by year. Among the most affected area by the impact of global warming is the sea. A study by The International Panel on Climate Change (IPCC) claimed that the warmer world can contribute to a further raise in sea level by expending ocean water. It is a concern when it was proven that the estimated global average sea level will increase between 0.6 and 2 feet (0.18-0.59 $\mathrm{m}$ ) in next 100 years (Solomon, 2007). Raising sea level will add the salinity of both surface water and ground water through salt water intrusion. If sea level increase pushes salty water upstream, then the existing water intakes might draw on salty water during dry periods. Additional salinity in estuaries also can harm sea fauna which are not suitable to live at the high salinity area. On top of it, the global warming also will affect cold and cool water species in low latitudes where extinction is expected to increase and biodiversity will decay. Doubtlessly, this will have impact on the quantity and quality of the marine fauna. Apart from this, global warming also brings threats to the coral reef (Bruno, 2010). As the coral reef extinct, it will destroy the habitat of some marine species such as fish and lobster. The sea current, waves action and wind velocity are not any longer stabile caused by global warming. Scientist claimed that the sea water flow will be slowed by the phenomena such as global warming and as a result of these; some parts of the world will be cooler or less warm as the rest of the globe swelters (Bazilchuk, 2009).

Bottom trawling: Bottom trawling is capable to endanger everything under the sea. Huge heavy nets are dragged along the sea floor in the process of bottom trawling. As a result, everything in the bottom along their path will be crushed by the large metal plates and rubber attached to the nets. Thus, the whole marine on the spots will be deposited into the nets despite the fact that only $50 \%$ is the actual target catch whereby others are wasted. Most crucial is that this technique is harmful to flora and fauna which include coral reef, sea mounts, dweller and others. The effect is worsen as the deep water flora and fauna require such a long time to recover from the destruction, they need decades to hundreds of years to heal and this is only if they are capable to do so, Consequently, our oceans will incapable to produce food sources for human consumption. Aside from that, the oceans will 
have lack of power to encounter disease and act as pollution filters. It had been proven that bottom trawling have ruined one third of the ocean. It creates concern as it has been claimed by several scientist that due to this destructive fishing practice, in fifty years due we could run out of seafood Gulf Coast Preservation Society 2010.

Fishing pressure: Fishing pressure happens when the rate of marine faunas reproduce is relatively lower than the rate of them had been captured. The rising demand of seafood is one of the contributing factors of this situation. Poor fisheries management and emergence of new fishing methods are making this condition greater than it already is. Fishing pressure problem might escalate from usage of ICT such as GPS and sonar. The issue of fishing pressure should not be ignored because if the issue is lightly taken and left uncheck, it will lead to extinction of marine ecosystem and risk the stability of food security to people all around the world who much depends on seafood as the sources of protein.

According to Worm et al. (2006), 75\% of the world fish stock reproduced slower than being harvested. It is significant for us to know that $80 \%$ of world fish have already been full oppressed or scarce in quantity. It has made known that if the trend continues, by 2050 the world fisheries would completely collapse. Table 1 further illustrate the effect of fishing pressure on the fisheries productivity in Malaysia. Referred to the statistic provided by DOF, the number of registered fishermen in Malaysia is escalating year by year, However, do the productivity of each fishermen increase as well? Started from 2006-2009, the average of marine fish landed per registered fishermen is continuously decreasing. It is an alarm to us that in 2009 the average of the marine fish landed per registered fishermen was the lowest (11.077 tonnes) Department of Fisheries Malaysia 2005-2009.

The impact of the negative environmental changes on the sea on the economic, social life and health of the fishermen: There is still lack of studies that try to reveal the impact of the negative environmental changes on the sea on the aspects of economic, social and health of the fishermen. These three elements are essential as it is important indicators of quality of life and a number of previous studies have proven on this (Hamdi et al., 2009; Yan and Wu, 2009; Cleveland, 2008; Zein, 2005; Zimmer and Ammornsirisomboon, 2001).

The productivity of the fisheries sector can be influenced by these negative environmental changes (Allison et al., 2007). Phenomena such as global warming for example is able to alter the temperature and precipitation are expected to have significant impact on sea fauna. The sea fauna may not be able to adapt to this change and their habitat can be destroyed (ex: coral reef). Negative threats would emerge from these changes where it can impoverish the fisheries sector in Malaysia for several incoming decades while marine ecosystems are adjusting. Many commercially valuable marine food sources may totally disappear from our waters and could affect the economic aspect of the fishermen. Furthermore, the unstable weather condition caused by global warming will result in difficulties among the fishermen to go out to the sea. Besides global warming, the sea has changed a lot due to the bottom trawling and fishing pressure activities. Bottom trawling for example will destroy everything under the sea while fishing pressure will cause the fish captures to exceed the limits. All of these will cause marine fish supply will keep reducing in the future and will have bad impact on the economic life of the fishermen.

The negative environmental changes especially one caused by the environmental factor do affect the health of the fishermen. One of the indirect effects of these changes would results in expansion of the area under the influence of Malaria mosquito and this is expected to increase the number of Malaria cases from $45 \%$ to $60 \%$ by the next half of the next century (Matsuoka and Kai, 1994). Besides, increase of the heart related diseases (asthma, allergic disorders and cardiorespiratory) would probably also occur due to the global warming. Previous studies conducted by Cline (1992) have revealed that global warming would increase the death rate by about $27-40$ persons per million populations. Other than these, skin disease, fever, flu and cough are also related with extreme temperature of global warming (Epstein, 2002) and when this happens it will result in lesser time for them to go out to the sea, thus lower their income.

The negative environmental changes on the sea have the potential to lower the community quality of social life. Tugwell et al. (2007) in his research has concluded that demographic factors such as gender, age, education, ethnicity, geography and language have different capacity in adapting to these changes. Global warming for example will bring social problems such as hunger, poverty and diseases like diarrhoea and malaria, disproportionately impact children. Those with weaker immune systems will become more vulnerable to diseases and changing climate (Tsai and Liu, 2005). The extreme temperature will demotivate people from doing their usual activities such as recreations and sports (Tucker and Gilliland, 2007). Extreme rain and storm due to global warming also can cause people to 
lose their home and basic facilities which directly can affect their social life. Shortage of food supply caused by global warming and illegal human activities on the sea (such as bottom trawling and fishing pressure) would also affect the social life of the community.

\section{MATERIALS AND METHODS}

This is a quantitative study. Based on simple random sampling employed, a total of 300 respondents were selected. The number was gained from four states in the east coast zone of Peninsular Malaysia namely Terengganu, Kelantan, Pahang and East Johor. Each of the states was represented by 75 respondents. The respondents were asked questions regarding the impact of the environmental changes on the sea on the three aspects of their QOL namely economy (7 questions), social (5 questions) and health (6 questions). The questions were constructed based on the past studies and literature reviews. Before going for actual data collection, the instrument was initially pre tested. Result of pre-test produced cronbach alpha value of .803 thus it exceeded the requirement determined by Egan (2005). For each of the questions asked, the respondents were given an option of five likert-like scale ranging from 1 represented highly disagree; 2 represented disagree; 3 represented moderately agree; 4 represented agree and 5 represented highly agree.
Survey was employed to gain the data needed. To fulfil the objective determined, analyses such as frequency, percentage, mean and standard deviation were employed.

\section{RESULTS}

Table 2 presents data regarding the respondents' background. Majority of the fishermen (26.3\%) were in the age group of 41-50. It is a concern as this industry is still lacking of future successors and this can be proven when only $14.1 \%$ of the respondents were in the age group of $\leq 30$ years old. It also can be found that a total of $15.7 \%$ of the respondents still working as fishermen even though their age are reaching $>61$ years. More than half of the respondents $(51.3 \%)$ possessed primary school level of education while only $0.3 \%$ of the respondents possessed degree/master/PhD level of education. The mean score recorded for income per month was RM669.62, however, majority of them (45.3\%) earned <RM500 per month. A total of $52.0 \%$ of the respondents have $\leq 5$ family household members compared to $48.0 \%$ who have $\geq 6$ household members. Majority of the respondents can be considered as a senior fisherman based on the mean score recorded for experience as a fisherman (25.1 years).

Table 2: Respondents background

\begin{tabular}{|c|c|c|c|c|}
\hline & Frequency & Percentage & Mean & SD \\
\hline$\overline{\text { Age (years) }}$ & & & 42.21 & 12.96 \\
\hline$\leq 30$ & 42 & 14.0 & & \\
\hline$\overline{3} 1-40$ & 57 & 19.0 & & \\
\hline $41-50$ & 79 & 26.3 & & \\
\hline $51-60$ & 75 & 25.0 & & \\
\hline$\geq 61$ & 47 & 15.7 & & \\
\hline \multicolumn{5}{|l|}{ Level of education } \\
\hline Never been to school & 21 & 7.0 & & \\
\hline Primary school & 154 & 51.3 & & \\
\hline $\mathrm{PMR} / \mathrm{SRP}$ & 55 & 18.3 & & \\
\hline SPM/SPMV & 66 & 22.0 & & \\
\hline Skill certificates & 3 & 1.0 & & \\
\hline Degree/Master/PhD & 1 & 0.3 & \multirow{5}{*}{669.62} & \multirow{5}{*}{724.71} \\
\hline Income per month (as a fisherman) (in ringgit Malaysia) & & & & \\
\hline$<500$ & 136 & 45.3 & & \\
\hline $501-750$ & 99 & 33.0 & & \\
\hline$>751$ & 65 & 21.7 & & \\
\hline Number of household & & & \multirow[t]{3}{*}{5.77} & \multirow[t]{3}{*}{2.53} \\
\hline$\leq 5$ members & 156 & 52.0 & & \\
\hline$>6$ members & 144 & 48.0 & & \\
\hline Experience as a fisherman (years) & & & \multirow[t]{6}{*}{25.10} & \multirow[t]{6}{*}{14.29} \\
\hline$<10$ & 61 & 20.3 & & \\
\hline $11-20$ & 82 & 27.3 & & \\
\hline $21-30$ & 58 & 19.3 & & \\
\hline $31-40$ & 56 & 18.7 & & \\
\hline$>41$ & 43 & 14.3 & & \\
\hline Average (days) going out to the sea for catching fish & & & \multirow[t]{7}{*}{18.90} & \multirow[t]{7}{*}{4.86} \\
\hline$<15$ & 93 & 31.0 & & \\
\hline $16-20$ & 118 & 39.3 & & \\
\hline$>21$ & 89 & 29.7 & & \\
\hline Category of fisherman & & & & \\
\hline Coastal area & 213 & 71.0 & & \\
\hline Deep sea & 87 & 29.0 & & \\
\hline
\end{tabular}


More than one third of the respondents $(39.3 \%)$ went to the sea for catching fish between 16-20 days in a month. A large majority of the respondents studied were coastal area fisherman.

Table 3 and 4 provide information regarding the impact of the environmental changes on the economic aspects of the fishermen. Table 3 presents the overall mean score for this aspect. To get the overall mean score, the cumulative value of seven statements included in the aspect was gained. Based on the overall mean score recorded of 3.59 , it can be concluded that the environmental changes has moderately affect the economic aspect of the fishermen. Results presented in Table 4 has revealed that the statements of the quantity of the fish landed are reducing recorded the highest mean score $(\mathrm{M}=4.03)$, followed by statement of "due to uncertain weather condition, it is difficult for me to go out to the sea for catching fish" $(\mathrm{M}=3.84)$ and statement of "the rise of water temperature causes potential catches to move into another basin" $(\mathrm{M}=3.70)$.

Table 5 presents information regarding the environmental changes impact on the aspect of health of the fishermen. Similar to the aspect of economic, to gain the overall mean score for this aspect, a cumulative value for this aspect was gained from five statements included. Based on the results gained $(\mathrm{M}=3.10)$ it can be seen that the environmental changes have moderately affect the health aspect of the fishermen. Referring to Table 6 , the respondents studied claimed that due to the uncertain weather condition nowadays they are always caught by cough $(\mathrm{M}=3.24)$, flu $(\mathrm{M}=$ 3.21) and fever $(M=3.14)$. However, the respondents claimed that their areas have a less number of dengue cases $(\mathrm{M}=2.64)$.

The last aspect studied was the social aspect. The overall mean score recorded was 2.96 thus reflects that the environmental changes do moderately affect the social aspects of the respondents studied.

Even though majority of the respondents claimed that the environmental changes moderately affect their social aspects, a total of $6.3 \%$ of the respondents were claiming that the environmental changes were highly affect their social aspects while a total of $19.0 \%$ of the respondents claimed that the environmental changes only have a low impact on their social aspects (Table 7).

Table 3: Overall level of the negative environmental changes on the sea and its impact on the economic aspects of the fishermen living in east coast zone of Peninsular Malaysia

\begin{tabular}{lccll}
\hline Aspect & Frequency & Percentage & Mean & SD \\
\hline Economic & & & 3.59 & 0.540 \\
Low (1-2.33) & 5 & 1.7 & & \\
Moderate (2.34-3.67) & 163 & 54.3 & & \\
High (3.68-5.00) & 132 & 44.0 & & \\
\hline
\end{tabular}

Table 4: Statements used to measure negative environmental changes on the sea and its impact on the economic aspects of the fishermen living in east coast zone of Peninsular Malaysia

\begin{tabular}{|c|c|c|c|c|c|c|c|}
\hline Statement & Strongly disagree & Disagree & Moderately agree & Agree & Strongly agree & Mean & SD \\
\hline $\begin{array}{l}\text { The quantity of the fish } \\
\text { landed are reducing }\end{array}$ & 1.7 & 3.7 & 10.7 & 58.0 & 26.0 & 4.03 & 0.815 \\
\hline $\begin{array}{l}\text { Due to uncertain weather } \\
\text { condition, it is difficult for me to } \\
\text { go out to the sea for catching fish }\end{array}$ & 3.3 & 6.7 & 12.0 & 58.7 & 19.3 & 3.84 & 0.926 \\
\hline $\begin{array}{l}\text { The rise of water temperature cause } \\
\text { potential catches to move into } \\
\text { another basin }\end{array}$ & 2.7 & 12.3 & 13.0 & 56.3 & 15.7 & 3.70 & 0.966 \\
\hline $\begin{array}{l}\text { There are some species (fish, crab } \\
\text {, prawn, cuttlefish) are extinct }\end{array}$ & 2.4 & 10.3 & 20.0 & 51.0 & 16.3 & 3.69 & 0.944 \\
\hline $\begin{array}{l}\text { Size of the fish landed are smaller } \\
\text { compared to the previous years }\end{array}$ & 2.0 & 17.0 & 15.0 & 47.7 & 18.3 & 3.63 & 1.03 \\
\hline $\begin{array}{l}\text { Boat and tools used to catch the fish } \\
\text { are damaged caused by the extreme } \\
\text { weather and need to be replaced }\end{array}$ & 1.0 & 15.7 & 28.3 & 40.7 & 14.3 & 3.52 & .955 \\
\hline $\begin{array}{l}\text { My income from my part time job } \\
\text { (tourism, recreations) are reducing } \\
\text { caused by less tourist/anglers come to } \\
\text { this place }\end{array}$ & 20.7 & 24.0 & 21.7 & 27.6 & 6.0 & 2.74 & 1.23 \\
\hline
\end{tabular}


Table 5: Overall level of negative environmental changes on the sea and its impact on the health aspects of the fishermen living in the east coast zone of Peninsular Malaysia

\begin{tabular}{lcccc}
\hline Aspect & Frequency & Percentage & Mean & SD \\
\hline Health & & & 2.96 & .586 \\
Low (1-2.33) & 57 & 19.0 & & \\
Moderate (2.34-3.67) & 224 & 74.7 & & \\
High (3.68-5.00) & 19 & 6.3 & & \\
\hline
\end{tabular}

Table 6: Statements used to measure negative environmental changes on the sea and its impact on the health aspects of the fishermen living in the east coast zone of Peninsular Malaysia

\begin{tabular}{|c|c|c|c|c|c|c|c|}
\hline Statement & $\begin{array}{l}\text { Strongly } \\
\text { disagree }\end{array}$ & Disagree & $\begin{array}{l}\text { Moderately } \\
\text { agree }\end{array}$ & Agree & $\begin{array}{l}\text { Strongly } \\
\text { agree }\end{array}$ & Mean & SD \\
\hline $\begin{array}{l}\text { Due to uncertain } \\
\text { condition now I } \\
\text { always have cough }\end{array}$ & 3.7 & 20.0 & 33.0 & 35.0 & 8.3 & 3.24 & 0.969 \\
\hline $\begin{array}{l}\text { Due to uncertain } \\
\text { weather condition } \\
\text { now I always have flu }\end{array}$ & 4.0 & 23.7 & 28.7 & 34.3 & 9.3 & 3.21 & 1.04 \\
\hline $\begin{array}{l}\text { Due to uncertain } \\
\text { weather condition } \\
\text { now I always } \\
\text { have fever }\end{array}$ & 5.3 & 22.3 & 32.0 & 33.3 & 7.0 & 3.14 & 1.02 \\
\hline $\begin{array}{l}\text { Due to uncertain } \\
\text { weather condition, it } \\
\text { causes problem to my }\end{array}$ & $\begin{array}{r}10.3 \\
\text { y skin }\end{array}$ & 33.3 & 19.0 & 29.0 & 8.4 & 2.92 & 1.17 \\
\hline $\begin{array}{l}\text { There are increasing } \\
\text { numbers of dengue } \\
\text { cases at my area }\end{array}$ & 12.3 & 36.0 & 29.7 & 19.3 & 2.7 & 2.64 & 1.01 \\
\hline
\end{tabular}

Table 7: Overall level of negative environmental changes on the sea and its impact on the social aspects of the fishermen living in the east coast zone of Peninsular Malaysia

\begin{tabular}{lcccc}
\hline Aspect & Frequency & Percentage & Mean & SD \\
\hline Social & & & 2.96 & .586 \\
Low (1-2.33) & 57 & 19.0 & & \\
Moderate (2.34-3.67) & 224 & 74.7 & & \\
High (3.68-5.00) & 19 & 6.3 & & \\
\hline
\end{tabular}

Table 8: Negative environmental changes on the sea and its impact on the social aspects of the fishermen living in the east coast zone of Peninsular Malaysia

\begin{tabular}{|c|c|c|c|c|c|c|c|}
\hline Statement & $\begin{array}{l}\text { Strongly } \\
\text { disagree }\end{array}$ & Disagree & $\begin{array}{l}\text { Moderately } \\
\text { agree }\end{array}$ & $\begin{array}{l}\text { Strongly } \\
\text { agree }\end{array}$ & y & Mean & SD \\
\hline $\begin{array}{l}\text { Food supply for my family } \\
\text { (from the catching) are } \\
\text { keep reducing }\end{array}$ & ly 3.7 & 16.0 & 25.0 & 46.7 & 8.7 & 3.41 & .979 \\
\hline $\begin{array}{l}\text { Due to uncertain weather } \\
\text { condition, there are } \\
\text { some facilities and } \\
\text { accommodation in } \\
\text { this area damaged and } \\
\text { need to be replaced }\end{array}$ & 2.7 & 24.0 & 31.7 & 28.3 & 13.3 & 3.26 & 1.05 \\
\hline $\begin{array}{l}\text { Due to uncertain weather } \\
\text { condition I hardly ever } \\
\text { went out with family } \\
\text { for holidays }\end{array}$ & 4.0 & 33.3 & 32.0 & 28.3 & 2.3 & 2.92 & .931 \\
\hline $\begin{array}{l}\text { Due to uncertain weather } \\
\text { condition, it hinders me } \\
\text { from doing my recreational } \\
\text { activities }\end{array}$ & $\begin{array}{r}4.0 \\
\text { al }\end{array}$ & 45.7 & 20.3 & 27.7 & 2.3 & 2.79 & .792 \\
\hline $\begin{array}{l}\text { Due to uncertain weather } \\
\text { condition it hinders me } \\
\text { from doing my social } \\
\text { activities (e.g., } \\
\text { fishermen gathering) }\end{array}$ & 10.3 & 38.3 & 27.0 & 20.7 & 3.7 & 2.69 & 1.03 \\
\hline $\begin{array}{l}\text { Due to uncertain } \\
\text { weather condition } \\
\text { I do not like leaving } \\
\text { the house for holidays." }\end{array}$ & 7.7 & 43.7 & 23.3 & 24.3 & 1.0 & 2.67 & .961 \\
\hline
\end{tabular}

It can be seen that the statement of "Food supply for my family (from the catching) are keep reducing "( $\mathrm{M}=3.41)$ followed by "Due to uncertain weather condition, there are some facilities and accommodation in this area damaged and need to be replaced" ( $\mathrm{M}=$ 3.26) while the statement of "Due to uncertain whether condition I hardly ever went out with family for holidays." ( $\mathrm{M}=2.92)$. The statement of "Due to uncertain weather condition I do not like leaving the house for holidays." recorded the lowest mean score (M $=2.67)$ (Table 8).

\section{DISCUSSION}

The environmental changes that occur on the sea bring harms to the economic aspects of the fishermen. The respondents studied have informed that the quantities of the fish and the number of days they can go out to the sea have reduced. Furthermore, they also reported extinction of some marine species from their catching area. Comparing the statistic that have been provided earlier, it is true that the productivity of marine fish landed was increasing year by year, but looking specifically at the quantity of fish landed per fishermen, indeed the productivity are reducing year by year. A number of causes can be related to this problem; among the causes are bottom trawling, global warming and fishing pressure. A lot of studies claimed that the environmental changes such as global warming will cause an increase of dengue cases in the area but not in this study. Only $22.0 \%$ of the respondents agreed and strongly agreed on the question related to the dengue cases in their areas while more than $48.0 \%$ of the respondents claimed that there are no dengue cases in their areas thus bring us to a probability that there are high awareness on dengue among the fishermen living in the east coast zone of Peninsular Malaysia. Fishermen studied claimed that they were always caught by fever, flu and cough, a common disease brought by uncertainties of weather. However this is not a major problem for them as currently there are 1,927 of rural clinics established in the rural areas of Malaysia and some of these clinics are located at the coastal areas in the east coast zone of Peninsular Malaysia. In term of impact on their social aspect, it can be clearly seen that majority of the respondents strongly agreed and agreed that food supply for family (from the sea catching) are keep reducing. The findings of this part are consistent with findings in the economic part where majority of the respondents strongly agreed and agreed that the quantity of fish landed are keep reducing. Referring to Table 9, it is not surprising this is happening as the quantities of the fish landed per fishermen in Malaysia are constantly reducing from 2005-2009. 
Am. J. Environ. Sci., 7 (6): 534-541, 2011

Table 9: Average of marine fish landings per registered fishermen

\begin{tabular}{lcll}
\hline & $\begin{array}{l}\text { Number of } \\
\text { registered } \\
\text { fishermen }\end{array}$ & $\begin{array}{l}\text { Total of marine } \\
\text { fish landed } \\
\text { (in tonnes) }\end{array}$ & $\begin{array}{l}\text { Average of marine } \\
\text { fish landed per registered } \\
\text { fishermen (in tonnes) }\end{array}$ \\
\hline 2005 & 90,702 & $1,209,601$ & 13.336 \\
2006 & 97,947 & $1,379,770$ & 14.087 \\
2007 & 99,617 & $1,381,424$ & 13.867 \\
2008 & 109,771 & $1,394,531$ & 12.704 \\
2009 & 125,632 & $1,391,579$ & 11.077 \\
\hline
\end{tabular}

\section{CONCLUSION}

Based on the results gained, it can be seen that the negative environmental changes have moderately affected the aspects of economic, social and health of the fishermen living in the east coast zone of Peninsular Malaysia. Most of the fishermen surveyed admitted that the quantity of the fish landed are keep reducing while the instability of the weather condition resulting in difficulties for them to go out to the sea and thus affecting their income. In term of health, the fishermen interviewed have informed that due to the instability of weather condition, they are frequently caught by cough, flu and fever. The fishermen also admitted that due the negative environmental changes, food supply for family (from the catching) are keep reducing and some facilities and accommodation in their area are damaged and need to be replaced.

\section{REFERENCES}

Allison, E.H., N.L. Andrew and J. Oliver., 2007. Enhancing the resilience of inland fisheries and aquaculture systems to climate change. ICRISAT, 4: $1-35$

Bazilchuk, N., 2009. In deep water: Will essential ocean currents be altered by climate change. Sci. Am.

Bruno, J., 2010. Coral reefs and climate change.

Cleveland, C., 2008. Environmental change and socioeconomic factors in Africa.

Cline, W.R., 1992. The Economics of Global Warming. 6th Edn., Peterson Institute, Washington, DC., ISBN: 088132132X, pp: 399.

D'Silva, J.L., N. Man, H.A.M, Shaffril and B.A. Samah, 2011. Acceptance of sustainable agricultural practices: The case of crop farmers. Am. J. Agric. Biol. Sci., 6: 227-230. DOI: 10.3844/ajabssp.2011.227.230

Egan, J.P., 2005. Research methodology in education. The University of British Columbia.
Epstein, P.R., 2002. Climate change and infectious disease: Stormy weather ahead? J. Epidemiol., 13: 373-375. PMID: 12094088

Hamdi, M.R., M. Abu-Allaban, A. Al-Shayeb, M. Jaber and N.M. Momani, 2009. Climate change in Jordan: A comprehensive examination approach. Am. J. Environ. Sci., 5: 58-68. DOI: 10.3844/ajessp.2009.58.68

Matsuoka, Y. and K. Kai, 1994. An estimation of climatic change effects on malaria. J. Global Environ. Eng., 1: 1-15.

Samah, B.A., H.A.M. Shaffril, M.A. Hassan and J.L. D'Silva, 2011. Can technology acceptance model be applied on the rural setting: The case of village development and security committee in Malaysia. J. Soc. Sci., 7: 113-119. DOI: 10.3844/jssp.2011.113.119

Shaffril, H.A.M., B.A, Samah, J.L, D'Silva and J.Uli, 2011. Global warming at the east coast zone of Peninsular Malaysia. Am. J. Agric. Biol. Sci., 6: 377-383. DOI: 10.3844/ajabssp.2011.377.383

Solomon, S., 2007. The Physical Science Basis: Contribution of Working Group I to the Fourth Assessment Report of the Intergovernmental Panel on Climate Change. 1st Edn., Cambridge University Press, Cambridge, New York, ISBN: 0521705967, pp: 996.

Tsai, H.T. and T.M. Liu, 2005. Effects of global climate change on disease epidemics and social instability around the world. Proceedings of the Human Security and Climate Change An International Workshop Holmen Fjord Hotel, Jun. 21-23, Asker, Oslo, pp: 1-13.

Tucker, P. and J. Gilliland, 2007. The effect of season and weather on physical activity: A systematic review. J. Public Health, 121: 909-922. DOI: 10.1016/j.puhe.2007.04.009

Tugwell, P., V. Robinson and E. Morris, 2007. Mapping global health inequalities: challenges and opportunities. eScholarship University of California, California.

Uli, J., J.L. D'Silva, H.A.M. Shaffril and B.A. Samah, 2010. The attitude, belief, support and knowledge level of the youth and their acceptance towards agriculture contract farming. J. Soc. Sci., 6: 350355. DOI: $10.3844 /$ jssp.2010.350.355

Worm, B., E.B. Barier, N, Beaumont, J.E. Duffy and C. Folke et al., 2006. Impacts of biodiversity loss on ocean ecosystem services. J. Sci., 314: 787-790. DOI: $10.1126 /$ science.1132294 
Yan, S. and G. Wu, 2009. What these trends suggest? Am. J. Applied Sci., 6: 1116-1121. DOI: 10.3844/ajassp.2009.1116.1121

Zein, A., 2005. The Role of Fisherwomen on Food Security at the Traditional fishermen Household of West Sumatera, Indonesia. Bung Hatta University, Padang, Indonesia.
Zimmer, Z. and P. Amornsirisomboon, 2001. Socioeconomic status and health among older adults in Thailand: an examination using multiple indicators. J. Soc. Sci. Med., 52: 1297-1311. DOI: $10.1016 / \mathrm{S} 0277-9536(00) 00232-\mathrm{X}$ 